\title{
Editorials
}

\section{Cannabinoids and pain management}

\author{
Orlando Hung BSc (Pharmacy) MD FRCPC, ${ }^{*}$ Mary E. Lynch MD FRCPC, $†$ Alexander J. Clark MD FRCPC
}

$\mathrm{H}$ ISTORY has not been kind to Cannabis sativa, a medicinal plant discovered and used by Asians for more than 10,000 years. While it may be one of the most commonly used and abused drugs worldwide, scientific knowledge of its therapeutic efficacy and safety remains unclear and controversial. Unpopular public perception and political roadblocks have hindered scientific advances of cannabis. This has led to a grave reluctance by the medical community to accept the drug as even being worthy of investigation. In fact, the acceptance of cannabis has not improved since the infamous 1936 movie "Reefer Madness" which cast a shadow over the use of cannabis by a high school student addicted to the "killer weed". He was subsequently sentenced to a mental hospital for life by a judge!

The modern study of cannabinoids began in 1964 when Mechoulam and colleagues first isolated and partially synthesized $\Delta^{9}$ - tetrahydrocannabinol (THC), which was later found to be the main psychoactive constituent of cannabis. ${ }^{1}$ Since that time substantial progress has been made with the identification of at least two cannabinoid receptors $\left(\mathrm{CB}_{1}\right.$ and $\left.\mathrm{CB}_{2}\right){ }^{2}$ a number of endogenous ligands, and the development of synthetic agonists and antagonists for both receptors. ${ }^{3} \mathrm{CB}_{1}$ receptors have been identified in pain processing areas from brain to the peripheral afferent receptor, whereas $\mathrm{CB}_{2}$ receptors are mostly found in peripheral tissues and possibly play a role in immune function modulation and regulation. Preclinical studies have identified that cannabinoid agonists exhibit analgesic effects in animal models of acute pain, with more profound effects in models of inflammatory and chronic neuropathic pain, ${ }^{4}$ suggesting a potential role of cannabinoids as analgesics.

In this issue of the Journal, Dr. Beaulieu conducted a comparative double-blind, randomized, placebo- controlled, parallel-group trial studying the analgesic effects of two different doses of nabilone, a synthetic analogue of THC, in managing acute postoperative pain following major surgery. ${ }^{5}$ Unfortunately, the study was prematurely terminated after 18 months. The results of this study demonstrated that nabilone administration was not associated with a decrease in morphine consumption in patients following major surgery. In addition, nabilone at high doses significantly increased pain scores at rest and upon movement. The investigator concluded that, although cannabinoids may be effective in relieving chronic pain in humans, their role in the treatment of acute postoperative pain is uncertain, and requires further clinical evaluation. Small sample size, early termination of the study, and the lack of standardization of surgical procedures with possible variation in intensity of postoperative pain (e.g., total hip replacement vs total knee replacement) may limit the conclusions that can be drawn from this study. Previous studies examining cannabinoids in treating postoperative pain have also demonstrated only a modest analgesic effect. ${ }^{6} \mathrm{~A}$ systematic review concluded that cannabinoids are no more effective than codeine in controlling acute pain, although this was a conclusion based upon only one Phase II study. ${ }^{7}$ While the current study suggests a very limited role for cannabinoids in postoperative pain, it is important to recognize that this may change as novel, more potent and more specific synthetic cannabinoid analogs, with limited central nervous system effects, are developed.

The role of cannabinoids in managing chronic pain is more promising. A systematic review of studies available prior to 2002 identified seven randomized controlled trials examining cannabinoids in chronic pain. These studies demonstrated that oral THC preparations exhibit a moderate analgesic effect, equivalent

From the Departments of Anesthesia, Surgery, and Pharmacology, ${ }^{*}$ Dalhousie University, Halifax, Nova Scotia; the Departments of Psychiatry, Anesthesia and Pharmacology, $\uparrow$ Queen Elizabeth II Health Sciences Centre, Halifax, Nova Scotia; and the Department of Anesthesia, $\ddagger$ University of Calgary, Calgary Health Region, Calgary, Alberta, Canada.

Address correspondence to: Dr. Orlando Hung, Department of Anesthesia, Queen Elizabeth II Health Sciences Centre, Victoria General Hospital, 1278 Tower Rd., Halifax, Nova Scotia B3H 3L1, Canada. Phone: 902-473-7767; Fax: 902-473-4493;

E-mail: orlando.hung@dal.ca

Disclosure statement: Dr. Orlando Hung has filed patents for cannabinoid delivery systems in US and PCT. 
to oral codeine, and that higher doses are associated with central effects, such as sedation. ${ }^{7}$ Subsequent randomized controlled trials using either synthetic THC, or cannabis extract have demonstrated a significant pain reduction in patients with multiple sclerosis or chronic pain. $^{8-12}$

The growing literature regarding cannabinoids as potential analgesics is of special interest to clinicians who are looking for alternative agents to treat chronic pain. Contemporary pharmacotherapeutic approaches to the management of chronic pain involve the use of a combination of agents that interact with monoaminergic, opioid, and N-methyl-D-aspartate receptors, as well as agents that modulate calcium and sodium channels and the prostaglandin system. ${ }^{13}$ Unfortunately, combinations of the currently available drugs often provide inadequate pain control and have side effects that can be debilitating. Alternative therapies with a variety of profiles are of continuous interest to pain and multiple sclerosis clinics. ${ }^{14-17}$

Unfortunately, there are two major problems associated with the use of cannabinoids: the lack of a suitable delivery system for the highly lipophilic cannabinoids; and the associated central nervous system side effects. Both have a negative impact on patient compliance and acceptance. The recent introduction of $s l$ or buccal delivery of cannabis extract is a positive development. ${ }^{11,12}$ Of major importance is the avoidance of the highly undesirable smoking of the cannabis leaf. In addition, synthetic cannabinoid compounds devoid of unwanted psychoactive side effects are now available and may help to reshape the future cannabinoid landscape. ${ }^{18,19}$

Many decades ago, little was known about the endogenous opioid system in pain modulation. Following the discovery of the opioid receptors and endogenous opiates in humans, there has been a dramatic improvement in the understanding of mechanisms of pain and the rational use of opiates. It is likely that the future of cannabinoids in pain management will replicate the opiate experience.

Whether we can redirect the history of the medical use of cannabis will depend on the collaborative efforts of the medical community, the support of granting agencies, regulatory tolerance, and the courageous leadership of our politicians. Inappropriate historical roadblocks must be removed and ethical research should be permitted to proceed unencumbered - to ensure that cannabinoids may be effectively and safely used to treat patients with pain. The presence of the endocannabinoid system demands that we investigate its potential role in pain management. We commend Dr. Beaulieu for his perseverance, courage and skill in the pursuit of this line of promising and much-needed scientific research in cannabinoids.

\section{Les cannabinoïdes et le contrôle de la douleur}

L'histoire n'a pas été tendre pour le Cannabis sativa, plante médicinale découverte et utilisée par les Asiatiques depuis plus de 10000 ans. C'est sans doute l'une des drogues dont on use et abuse le plus dans le monde, mais la connaissance scientifique de son efficacité et de son innocuité thérapeutiques demeure confuse et controversée. La perception impopulaire du public et des obstacles politiques ont retardé la recherche sur le cannabis. Ce qui a provoqué une importante réticence des médecins à admettre que le cannabis méritait au moins qu'on l'étudie. De fait, l'acceptation du cannabis ne s'est pas améliorée depuis «Reefer Madness», film tristement célèbre de 1936 qui jetait une ombre sur l'usage du cannabis par un adolescent dépendant de l'«herbe meurtrière» et condamné par un juge à l'internement à vie dans un hôpital psychiatrique!

L'étude moderne des cannabinoïdes a commencé en 1964 quand Mechoulam et ses collègues ont, pour la première fois, isolé et partiellement synthétisé le $\Delta^{9}$ - tétrahydrocannabinol (THC), identifié plus tard comme le principal composant psychoactif du cannabis. ${ }^{1}$ Depuis, de grands progrès ont été réalisés avec la découverte d'au moins deux récepteurs cannabinoïdes $\left(\mathrm{CB}_{1}\right.$ et $\left.\mathrm{CB}_{2}\right),{ }^{2}$ un certain nombre de ligands endogènes et l'élaboration d'agonistes et d'antagonistes synthétiques pour les deux récepteurs. ${ }^{3}$ Les récepteurs $\mathrm{CB}_{1}$ ont été identifiés dans les centres de la douleur allant du cerveau vers le récepteur périphérique afférent, tandis que les récepteurs $\mathrm{CB}_{2}$ sont situés surtout dans les tissus périphériques et ont probablement un rôle dans la modulation et la régulation de la fonction immunitaire. Des études précliniques ont montré que les agonistes cannabinoïdes présentent des effets analgésiques chez des modèles animaux de douleur aiguë, et que des effets plus intenses sont notés chez des modèles de douleur inflammatoire et neuropathique chronique, ${ }^{4}$ ce qui laisse croire à un rôle analgésique possible.

Dans le présent numéro du Journal, le Dr Beaulieu présente l'étude comparative, à double insu, randomisée et contrôlée contre placebo, de groupes parallèles 
qu'il a menée sur les effets analgésiques de deux doses différentes de nabilone, un analogue synthétique de la THC, pour traiter la douleur aiguë après une opération importante. ${ }^{5}$ L'étude a dû être prématurément arrêtée après 18 mois. Les résultats ont démontré que le nabilone ne diminuait pas la consommation de morphine après une opération importante. En outre, à fortes doses, il augmentait de façon significative les scores de douleur au repos et pendant le mouvement. Le chercheur en a conclu que, même si les cannabinoïdes sont efficaces pour soulager la douleur chronique chez l'humain, leur action contre la douleur postopératoire aiguë est incertaine et exige une évaluation clinique plus poussée. La petite taille de l'échantillon, la fin précoce de l'étude et le manque de standardisation des interventions chirurgicales comportant une variation possible de l'intensité de la douleur, entre une arthroplastie totale de la hanche et la pose d'une prothèse totale du genou par exemple, peut limiter les conclusions à tirer de cette étude. Des études antérieures sur l'usage postopératoire des cannabinoïdes n'avaient aussi montré qu'un modeste effet analgésique. ${ }^{6}$ Une revue systématique a conclu que les cannabinoïdes ne sont pas plus efficaces que la codéine dans le contrôle de la douleur aiguë, quoique cette conclusion soit fondée sur une seule étude de phase II. ${ }^{7}$ La présente étude ne suggère qu'un rôle très limité des cannabinoïdes contre la douleur postopératoire, mais il est important de reconnaître que la situation peut changer avec l'arrivée de nouveaux analogues de cannabinoïdes synthétiques plus puissants et plus spécifiques.

Le rôle des cannabinoïdes dans le traitement de la douleur chronique est plus prometteur. Une revue systématique d'études antérieures à 2002 a recensé sept essais randomisés et contrôlés sur le sujet. Ces études ont démontré que les préparations orales de THC affichent un effet analgésique modéré, équivalent à la codéine orale et que de fortes doses sont associées à des effets centraux, comme la sédation. ${ }^{7}$ Des études randomisées et contrôlées subséquentes portant sur des THC synthétiques ou des extraits de cannabis ont montré une réduction significative de la douleur chez des patients atteints de sclérose en plaques ou de douleur chronique. ${ }^{8-12}$

La documentation croissante sur les cannabinoïdes comme analgésiques possibles présente un intérêt particulier pour ceux qui cherchent de nouveaux analgésiques pour la douleur chronique. La pharmacothérapie moderne utilise une combinaison de médicaments qui interagissent avec les récepteurs monoaminergiques, opioïdes et $\mathrm{N}$-méthyl-D-aspartate, autant comme agent de modulation des canaux calciques et sodiques que du système de prostaglandine. ${ }^{13}$ Mais les combinaisons présentement offertes ne contrôlent souvent la douleur qu'en partie et ont des effets secondaires parfois débilitants. Des traitements de substitution aux profils variés sont toujours intéressants contre la douleur et la sclérose en plaques. ${ }^{14-17}$

Cependant, deux problèmes importants sont associés aux cannabinoïdes : l'absence d'un système d'administration approprié pour les cannabinoïdes hautement lipophiles et les effets secondaires sur le système nerveux central. Ces problèmes nuisent à la collaboration et à l'acceptation du patient. L'introduction récente de l'administration $s l$ ou orale d'extrait de cannabis est une avancée positive. ${ }^{11,12}$ Il faut éviter l'effet hautement indésirable de l'habitude de fumer les feuilles de cannabis. De plus, des composés de cannabinoïdes synthétiques dépourvus d'effets secondaires psychoactifs non désirés sont maintenant accessibles et pourraient aider à remodeler le paysage futur des cannabinoïdes. ${ }^{18,19}$

Il y a de nombreuses décennies, on en savait peu sur le système opioïde endogène dans la modulation de la douleur. Après la découverte des récepteurs opioïdes et des opiacés endogènes chez l'humain, il y a eu une amélioration considérable de la compréhension des mécanismes de la douleur et de l'usage réfléchi des opiacés. Il y a fort à parier que l'avenir des cannabinoïdes dans le traitement de la douleur sera une reproduction de l'expérience avec les opiacés.

La possibilité de réorienter l'histoire de l'usage médical du cannabis dépend des efforts de collaboration du milieu médical, du soutien des organismes subventionnaires, d'une tolérance régulatrice et de l'initiative courageuse de nos politiciens. Il faut éliminer les obstacles historiques non fondés et permettre d'avancer sans contrainte par une recherche éthique qui s'assure que les cannabinoïdes peuvent être utilisés en toute efficacité et sécurité pour traiter la douleur. La présence du système des endocannabinoïdes exige que nous fassions des essais sur son rôle analgésique potentiel. Nous pouvons remercier le Dr Beaulieu pour la persévérance, le courage et la compétence qu'il a montrés dans la poursuite de la recherche scientifique qui s'impose dans ce domaine prometteur.

\section{References}

1 Gaoni $\Upsilon$, Mechoulam R. Isolation, structure and partial synthesis of an active constituent of hashish. J Am Chem Soc 1964; 86: 1646-7.

2 Pertwee RG, Ross RA. Cannabinoid receptors and their ligands. Prostaglandins Leukot Essent Fatty Acids 2002; 66: 101-21.

3 Lynch ME. Preclinical science regarding cannabinoids 
as analgesics: an overview. Pain Res Manag 2005; 10(Suppl A): 7A-14A.

4 Walker JM, Strangman NM, Huang SM. Cannabinoids and pain. Pain Res Manag 2001; 6: 74-9.

5 Beaulieu P. Effects of nabilone, a synthetic cannabinoid, on postoperative pain. Can J Anesth 2006; 53 : 769-75.

6 Jain AK, Ryan JR, McMabon FG, Smith G. Evaluation of intramuscular levonantradol and placebo in acute postoperative pain. J Clin Pharmacol 1981; 21 (8-9 Suppl): 320S-6S.

7 Campbell FA, Tramer MR, Carroll D, Reynolds DJ, Moore RA, McQuay HJ. Are cannabinoids an effective and safe treatment option in the management of pain? A qualitative systematic review. BMJ 2001; 323: 13-6.

8 Svendsen KB, Jensen TS, Bach FW. Does the cannabinoid dronabinol reduce central pain in multiple sclerosis? Randomised double blind placebo controlled crossover trial. BMJ 2004; 329: 253.

9 Zajicek J, Fox P, Sanders H, et al. Cannabinoids for treatment of spasticity and other symptoms related to multiple sclerosis (CAMS study): multicentre rendomised placebo-controlled trial. Lancet 2003; 362: 1517-26.

10 Zajicek JP, Sanders HP, Wright DE, et al. Cannabinoids in multiple sclerosis (CAMS) study:safety and efficacy data for 12 months follow up. J Neurol Neurosurg Psychiatry 2005; 76: 1664-9.

11 Berman JS, Symonds C, Birch R. Efficacy of two cannabis based medicinal extracts for relief of central neuropathic pain from brachial plexus avulsion: results of a randomised controlled trial. Pain 2004; 112: 299-306.

12 Rog DJ, Nurmikko TJ, Friede T, Young CA. Randomized, controlled trial of cannabis-based medicine in central pain in multiple sclerosis. Neurology 2005; 65: 812-9.

13 Lynch ME, Watson CP. The pharmacotherapy of chronic pain: a review. Pain Res Manag 2006; 11: 11-38.

14 Ware MA, Doyle CR, Woods R, Lynch ME, Clark AJ. Cannabis use for chronic non-cancer pain: results of a prospective survey. Pain 2003; 102: 211-6.

15 Clark AJ, Ware MA, Yazer E, Murray TJ, Lynch ME. Patterns of cannabis use among patients with multiple sclerosis. Neurology 2004; 62: 2098-2100.

16 Ogborne AC, Smart RG. Cannabis users in the general Canadian population. Subst Use Misuse 2000; 35: 301-11.

17 Ogborne AC, Smart RG, Weber T, Birchmore-Tmney $C$. Who is using cannabis as a medicine and why: an exploratory study. J Psychoactive Drugs 2000; 32: 435-43.

18 Burstein SH. The cannabinoid acids: nonpsychoactive derivatives with therapeutic potential. Pharmacol Ther
1999; 82: 87-96

19 Sumariwalla PF, Gallily L, Tchilibon S, Fride E, Mechoulam R, Feldmann M. A novel synthetic, nonpsychoactive cannabinoid acid (HU-320) with antiinflammatory properties in murine collagen-induced arthritis. Arthritis Rheum 2004; 50: 985-98. 